\title{
OVULATION AND ASSOCIATED HISTOLOGICAL CHANGES IN THE OVARY FOLLOWING COITUS IN THE VOLE (MICROTUS AGRESTIS)
}

\author{
W. G. BREED* AND J. R. GLARKE \\ Department of Agricultural Science, Parks Road, Oxford
}

(Received 9th February 1970)

The vole (Microtus agrestis) is an induced ovulator (Austin, 1957a; Breed, 1967) but the interval between copulation and ovulation is not accurately known. Ovulation occurs 9 to $12 \mathrm{hr}$ after injection of pregnancy urine gonadotrophin (Austin, 1957a) but following natural mating, uncleaved eggs or eggs with one cleavage were found in Fallopian tubes $24 \mathrm{hr}$ later (Austin, 1957b). The present study was undertaken to determine the time between coitus and ovulation and to ascertain the associated histological changes in the ovary.

Virgin females were placed in cages with virile males, one pair/cage, and observed for 5 to $30 \mathrm{~min}$, after which the pairs were separated. Three females were killed at various stages between 2 to 4 and 18 to $20 \mathrm{hr}$ post coitum (p.c.). Ovaries were removed, sectioned at $7 \mu$, stained with haematoxylin and eosin and vesicular follicles and corpora lutea (CL) measured and counted as described by Breed (1969).

Between 2 and $8 \mathrm{hr}$ p.c., the discus proligerus of the follicles became increasingly separated from the membrana granulosa, strongly staining eosinophilic material appeared around the dispersing discus cells and a corona radiata around the oocyte (Pl. 1, Figs. 1 and 2). No membrane was visible around the nucleus of the ovum by 2 to $4 \mathrm{hr}$ p.c., and by 6 to $8 \mathrm{hr}$ the nucleus was in telophase. Follicles having these characteristics are not seen in virgin females and, hence, are classified as pre-ovulatory follicles.

By $9 \mathrm{hr}$ p.c., one female had seven pre-ovulatory follicles in which the theca interna was especially prominent (Pl. 1, Fig. 1) and 1st polar bodies were seen adjacent to the ova. The second female had two such follicles, as well as one in which the ovum lay free in the antral cavity surrounded by eosinophilic material which extended through a pore in the follicle and another follicle with an almost extruded ovum. Two GL present had slit-like cavities (Pl. 1, Fig. 3) and larger, less darkly stained nuclei nearer the periphery (Pl. 1, Fig. 4). The third female had four such CL and no pre-ovulatory follicles. By 16 hr p.c., luteal cells had become eosinophilic and few capillaries and connective tissue cells were visible among them. The cavity in the CL tended to become larger and more spherical as the time elapsed after coitus. A cluster of small cells with pycnotic nuclei usually occurred in the cL (Pl. 1, Fig. 5). Rupture points were often not visible.

Two types of follicles, not observed at earlier stages, were present 10 to $20 \mathrm{hr}$

* Present address : Department of Anatomy, Medical School, Birmingham 15. 
p.c. One type (luteinized follicles) had cells similar in cytological appearance to those of the accompanying $\mathrm{CL}$, but also contained oocytes lying free in the antral cavities surrounded by intensely staining eosinophilic material. The second type (minimally stimulated follicles) showed no luteinization and had centrally placed oocytes surrounded by an eosinophilic reticular network amongst which groups of granulosa cells were often detectable. First polar bodies often lay adjacent to the oocytes (Pl. 1, Fig. 6).

Table 1 shows that, from 2 to $12 \mathrm{hr}$ p.c., pre-ovulatory follicles occurred but none were present after this time, whereas cL first appeared 8 to $10 \mathrm{hr}$ p.c. and subsequently were invariably present. A few luteinized and minimally stimulated follicles occurred between 10 and $20 \mathrm{hr}$ p.c., whereas only five of the twentyseven females had Graafian follicles present.

Of the fourteen females that had pre-ovulatory follicles, only four had follicles larger than $700 \mu$ and none of these exceeded $750 \mu$. There was no

TABLE 1

NUMBERS OF FOLLICLES AND GORPORA LUTEA

\begin{tabular}{|c|c|c|c|c|c|}
\hline $\begin{array}{l}\text { Time after } \\
\text { coitus* } \\
\text { (hr) }\end{array}$ & $\begin{array}{c}\text { Pre-ovulatory } \\
\text { follicles } \\
\text { (Mean } \pm \text { S.E. })\end{array}$ & $\begin{array}{c}C L \\
(M e a n \pm S . E .)\end{array}$ & $\begin{array}{c}\text { Luteinized } \\
\text { follicles } \\
(\text { Mean } \pm \text { S.E. })\end{array}$ & $\begin{array}{c}\text { Minimally } \\
\text { stimulated } \\
\text { follicles } \\
(\text { Mean } \pm S . E .)\end{array}$ & $\begin{array}{l}\text { Graafian } \\
\text { follicles } \\
\text { (Total) }\end{array}$ \\
\hline $\begin{array}{l}2 \text { to } 4 \\
4 \text { to } 6 \\
6 \text { to } 8 \\
8 \text { to } 10 \\
10 \text { to } 12 \\
12 \text { to } 14 \\
14 \text { to } 16 \\
16 \text { to } 18 \\
18 \text { to } 20\end{array}$ & $\begin{array}{c}6 \cdot 7 \pm 1 \cdot 8(3) \\
6 \cdot 3 \pm 0.9(3) \\
5 \cdot 3 \pm 1 \cdot 3(3) \\
4 \cdot 3 \pm 1 \cdot 7(2) \\
1 \cdot 7 \pm 0.3(3) \\
0 \\
0 \\
0 \\
0\end{array}$ & $\begin{array}{c}0 \\
0 \\
0 \\
2 \cdot 0 \pm 1 \cdot 5(2) \\
3 \cdot 3 \pm 0.3(3) \\
3 \cdot 6 \pm 0 \cdot 3(3) \\
4 \pm 0(3) \\
4 \pm 0(3) \\
3 \cdot 6 \pm 0 \cdot 3(3)\end{array}$ & $\begin{array}{c}0 \\
0 \\
0 \\
0 \\
0 \cdot 3 \pm 0 \cdot 3(1) \\
0 \cdot 7 \pm 0 \cdot 6(2) \\
0 \cdot 3 \pm 0 \cdot 3(1) \\
0 \cdot 3 \pm 0 \cdot 3(1) \\
0 \cdot 3 \pm 0 \cdot 3(1)\end{array}$ & $\begin{array}{c}0 \\
0 \\
0 \\
0 \\
1 \cdot 0 \pm 0.6(2) \\
1 \cdot 0 \pm 0.6(2) \\
0 \\
1 \cdot 3 \pm 0.3(3) \\
0.7 \pm 0.7(1)\end{array}$ & $\begin{array}{l}0 \\
0 \\
1 \\
0 \\
1 \\
2 \\
0 \\
2 \\
1\end{array}$ \\
\hline
\end{tabular}

* Three animals killed at each 2-hr interval.

( ) No. of voles with follicles or CL in respective category.

obvious enlargement of the pre-ovulatory follicles with increase in time after coitus. Graafian follicles did not exceed $440 \mu$. cL varied in size from $525 \pm$ $33 \mu$ (8 to $10 \mathrm{hr}$ p.c.) to $581 \pm 15 \mu$ (18 to $20 \mathrm{hr}$ p.c.). Luteinized follicles were similar in size to the accompanying CL (range 532 to $653 \mu$ ), but minimally stimulated follicles were smaller (range 520 to $488 \mu$ ).

Ovulation in the vole can, therefore, occur $9 \mathrm{hr}$ after coitus and all competent follicles have ovulated within $12 \mathrm{hr}$ of mating. Similar results have been obtained for the rabbit (Walton \& Hammond, 1929) and Microtus ochrogaster (Richmond \& Conaway, 1969) but in the ferret, mink and cat, the interval is longer (see Everett, 1961).

Histological changes in pre-ovulatory follicles were similar to those described for other species, but the vole differs from most, including Microtus californicus (Greenwald, 1956) and Clethrionomys glareolus (Brambell, 1956), by not showing swelling of the pre-ovulatory follicles before ovulation.

Structures similar to minimally stimulated follicles are not found in mature virgin voles but have been observed in young rats treated with human chorionic 
PI.STE I
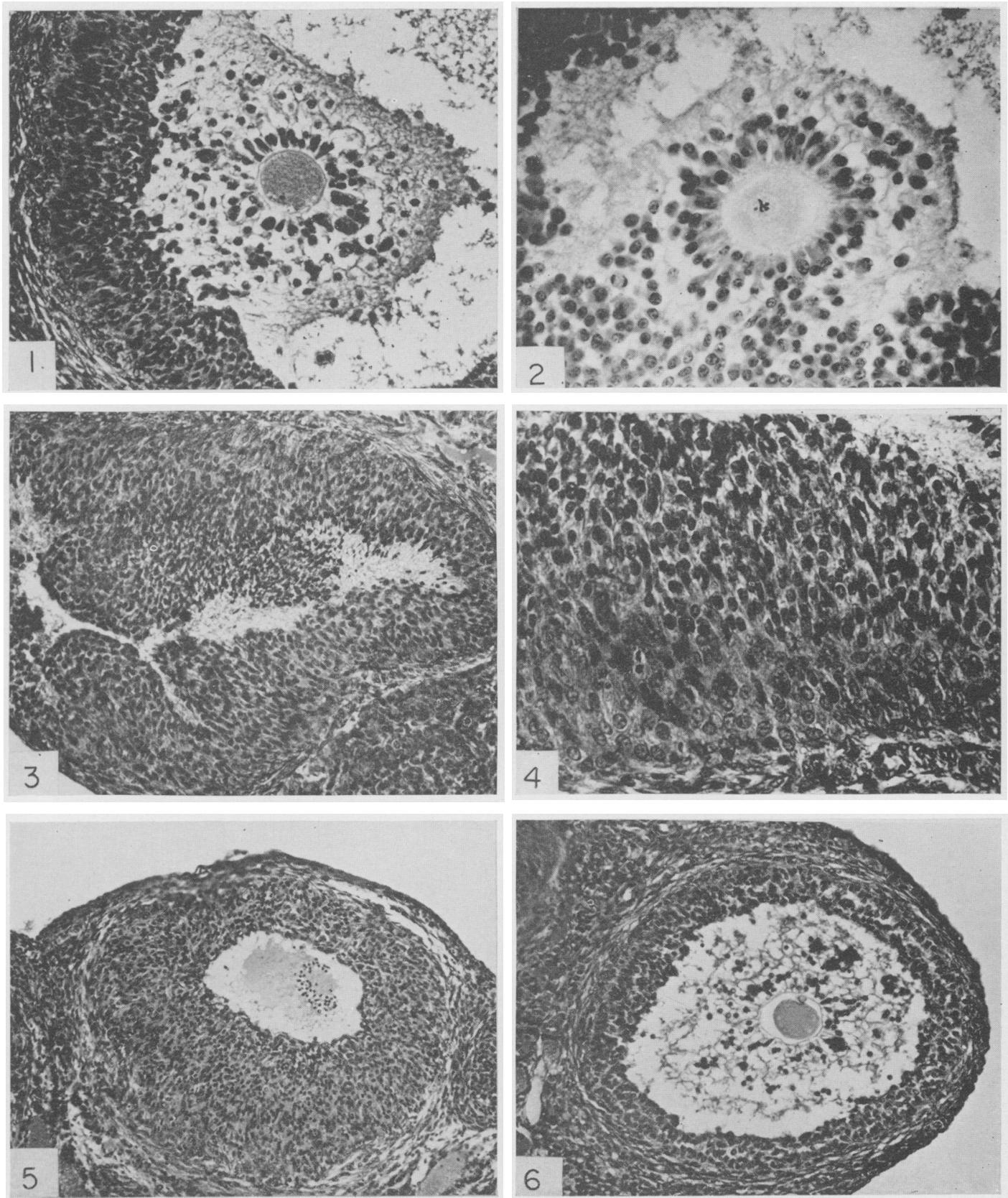

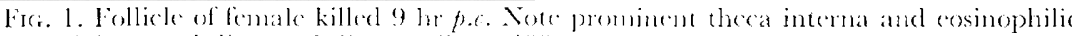
material arenend dispersed discus colls. $\times 200$.

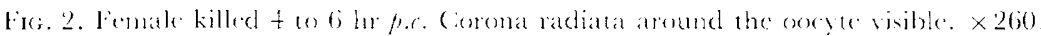

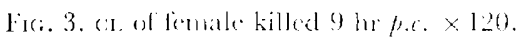

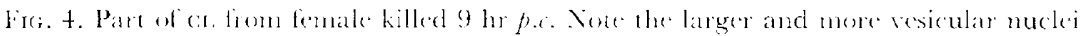
neares the periphery. $\times 260$.

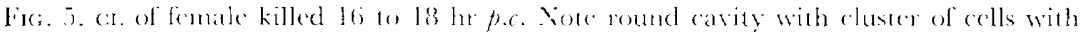
pyonotic nucleis. $x$ J(m).

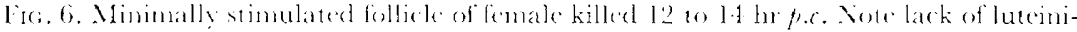

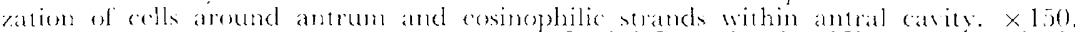


gonadotrophin (I. W. Rowlands, personal communication). These, together with luteinized follicles, may have received either an insufficient supply of ovulating hormone or were not sufficiently mature to complete the ovulatory process. The small diameters of the minimally stimulated follicles suggests the latter conclusion. Since unaltered Graafian follicles were rare, it appears that, following coitus, nearly all Graafian follicles undergo pre-ovulatory changes which are not observed after a large dose of luteinizing hormone is administered (Breed, unpublished observations).

We are indebted to Professor G. E. Blackman for providing facilities for this work and to Mrs J. Day for invaluable technical assistance. W.G.B. was supported by a Ministry of Agriculture, Food and Fisheries postgraduate studentship.

\section{REFERENCES}

Austin, G. R. (1957a) Oestrus and ovulation in the field vole (Microtus agrestis). F. Endocr. 15, iv.

Austin, C. R. (1957b) Fertilization, early cleavage, and associated phenomena in the field vole (Microtus agrestis). F. Anat. 91, 1.

Brambell, F. W. R. (1956) Ovarian changes. In: Marshall's Physiology of Reproduction, 3rd edn, Vol. 1, Part 1. Ed. A. S. Parkes. Longmans Green, London.

BREED, W. G. (1967) Ovulation in the genus Microtus. Nature, Lond. 214, 826.

BREED, W. G. (1969) Oestrus and ovarian histology in the lactating vole (Microtus agrestis). F. Reprod. Fert, 18, 33.

EveretT, J. W. (1961) The mammalian female reproductive gycle and its controlling mechanism. In: Sex and Internal Secretions, 3rd edn. Ed. W. C. Young. Williams \& Wilkins, Baltimore.

Greenwald, G. S. (1956) The reproductive cycle of the field mouse (Microtus califormicus). F. Mammal. $37,213$.

Richmond, M. \& Conaway, C. H. (1969) Induced ovulation and oestrus in Microtus ochrogaster. $\mathcal{J}$. Reprod. Fert. Suppl. 6, 357.

Walton, A. \& HAMmOND, J. (1929) Observations on ovulation in the rabbit. J. exp. Biol. 6, 190. 